\title{
EMPLOYMENT STATUS, FAMILY INCOME, CONTRACEPTIVE AVAILABILITY, AND THEIR EFFECTS ON THE USE OF LONG TERM CONTRACEPTIVES IN SUKOHARJO, CENTRAL JAVA
}

\author{
Sri Setiyo Ningrum ${ }^{1,2)}$, Dono Indarto²,3), Mahendra Wijaya ${ }^{2,4)}$ \\ 1)Diploma III Program in Midwifery, Poltekkes Bhakti Mulia, Sukoharjo \\ 2)Masters Program in Public Health, Sebelas Maret University \\ 3)Faculty of Medicine, Sebelas Maret University \\ 4)Faculty of Social and Political Sciences, Sebelas Maret University
}

\begin{abstract}
Background: Rapid population growthcause population burden on earth and imbalance population distribution. This situation in turn make cause public health and social problems. One of the methods that can be used to control population growth is long term contraceptive use. The Indonesian Demographic and Health Survey (SDKI) showed that employed mothers were more likely to use long term contraceptive than unemployed mothers. Contraceptives are available for free at Family Planning Clinic (KKB). This study aimed to analyze the effect of employment status, family income, and contraceptive availability, on the use of long term contraceptive among women and men of reproductive age in Sukoharjo, Central Java.

Subjects and Method: This was a qualitativeanalytic and descriptive study with phenomenology approach. This study was conducted in Weru, Kartasura, Polokarto, and Tawangsari subdistricts, Sukoharjo, Central Java. The key informants included acceptors of implant, IntraUterine Device (IUD), Female Surgical Method(MOW), and Male Surgical Method(MOP). The data were collected by in-depth interview, Focus Group Discussion (FGD), observation, document review. The data were alayze by interactive analysis. The data were verified by triangulation of data sources.
\end{abstract}

Results: Two informants reported they chose IUD because they had to work outside the house, undesirable side effects of using oral contraceptive, injection contraceptive, and contraceptive use by their mothers and grandmothers. Some other informants have used implant because of undesirable side effect of using injection contraceptive, such as irregular menstruation and increased body weight. Two other informants have used female surgical method (MOW) because they already have three children and do not want to be pregnant again. Onemale informant reported that hehas used male surgical method (MOP) because already has four children, and he followed the methods his father has used. Most of the long term contaceptive users work outside the house and their incomes were lower than the minimum regional standard wage. Most of the long term contraceptive users receive free contraceptive and additional reward (e.g. free rice). The remaining long term contraceptive users buy contraceptives at the health center and hospital. The contraceptives were supplied by the National Coordinating Board of Population and Family Planning (Badan Kependudukan dan Keluarga Berencana Nasional, BKKBN) at province level. Village midwives did not receive free contraceptive because their practices have not been classified as Family Planning Clinics(KKB). 
Conclusion:Availability of contraceptive is a necessary condition for long term contraceptive use. Working outside the house is an additional factor for most women to realize long term contraceptive use.

Keyword: Employment status, family income, availability, long term contraceptive

Correspondence: Sri Setiyo Ningrum. Diploma III Program in Midwifery, Poltekkes Bhakti Mulia, Sukoharjo, Central Java.

Email: srisetiyoningrum@ymail.com. 